Канд. техн. наук Д.В. Константінов, M.I. Мисько

\title{
ДОСЛІДЖЕННЯ ПЕРСПЕКТИВНИХ СИСТЕМ ДИСПЕТЧЕРСЬКОГО УПРАВЛІННЯ НА ОСНОВІ СУЧАСНИХ ІНФОРМАЦІЙНИХ ТЕХНОЛОГІЙ
}

\author{
Представив д-р техн. наук, профессор С.С. Альошинський
}

\begin{abstract}
Вступ. В час інформаційних технологій країни з розвинутою мережею залізниць впроваджують інформаційні системи для допомоги диспетчерському персоналу в організації перевізного процесу.
\end{abstract}

Актуальність.

Диспетчерський персонал - одна 3 найголовніших ланок у перевізному процесі на залізничному транспорті. За зміну він ухвалює велику кількість рішень з організації перевізного процесу. У багатьох країнах світу постає задача допомоги в правильному прийнятті рішень $з$ організації руху поїздів.

Постановка задачі. Розвиток систем диспетчерського управління $є$ важливим 
кроком на шляху розвитку залізниць. Тому для досягнення максимальної ефективності у вирішенні цього питання доцільним $\epsilon$ дослідження вітчизняного та закордонного досвіду розробки системи диспетчерського управління.

Основний матеріал. В США, Канаді, Японії, Великобританії і в інших країнах створені автоматизовані диспетчерські центри управління (АДЦУ) з загальними залами для чергового персоналу, загальними інформаційними табло i індивідуальними автоматизованими робочими місцями (АРМ) для диспетчерів. За допомогою АДЦУ забезпечують керування експлуатаційною роботою на великих залізничних полігонах, а в Італії та Данії - на території всієї країни [1].

В США найбільша кількість ЕВМ використовується для автоматизації управління роботою сортувальних станцій і в системах диспетчерської централізації.

Залізнична компанія UnionPacificRailways ввела в експлуатацію автоматизовану систему диспетчерського управління рухом поїздів на базі EBM (ATCS), що дозволяє регулювати рух 200250 поїздів на полігонах 32000 км залізниць США і Канади. Система передбачає підвищення швидкості і безпеки руху поїздів, раціональне використання енергоресурсів локомотивами і підвищення продуктивності праці обслуговуючого персоналу [1].

Одна 3 найбільших в США залізничних компаній - Berlington Norten на початку 1995 р. ввела в експлуатацію новий автоматизований центр управління експлуатаційною роботою (ЦУПП) в ФортУерте з метою поетапного сконцентрування контролю i управління роботою всього полігону залізниці 3 експлуатаційною довжиною близько 37350 км і оборотом щодобово 500-600 поїздів [1].

В диспетчерському залі площею 4200 кв. м віялоподібно в трьох ярусах знаходяться АРМ диспетчерів i іншого персоналу. Сюди відразу перевели персонал трьох із семи регіональних центрів управління. Всього в ЦУПП функціонує 92 АРМ, забезпечує управління рухом поїздів, локомотивним парком i поїзними бригадами.

Робота диспетчерів переведена на безпаперову технологію: ДЦ на магістральних лініях, автоматичне маршрутне управління, управління обгонами i схрещенням поїздів, регулювання рухом на неосигналізованих полігонах 3 використанням радіозв'язку, ведення графіка виконаного руху поїздів, робота 3 обмеження швидкості руху, підготовки звіту про запізнення поїздів і т. ін.

На канадських національних залізницях базовий центр автоматизованого управління перевезеннями знаходиться у Вінніпегу. 31991 р. функціонує Центр управління перевезеннями в Монреалі. На великий екран виводиться інформація про всі поїзди, що знаходяться на дільницях між виділеними станціями. При цьому чотирма різними кольорами показується рух поїздів з обліком величини відхилення від графіка. Окремо помічаються поїзди 3 небезпечними вантажами. На АРM операторів можна вивести різні дані про облік i звіт. Моделювання дозволяє періодично корегувати графік руху поїздів [1].

Об'єднаний центр управління (ОЦУ) в штаб-квартирі канадських національних залізниць почав діяти в 1991 p. та забезпечує управління рухом поїздів на полігоні протяжністю 30000 км. ОЦУ використовує автоматизовану систему TOРС (планування поїзної роботи) і MPS (складання графіка обертання локомотивів i прив'язка їх до поїзда).

Диспетчери можуть переглядати поточне поїзне положення за останні 24 год і вперед на 48 год.

Робоче місце локомотивних диспетчерів знаходиться безпосередньо перед табло; за ними знаходиться АРМ головного локомотивного диспетчера. Далі розміщуються комп'ютеризовані АРM 
поїзних диспетчерів, на яких відображаються схеми певних диспетчерських кіл.

В Японії в 1995 р. компанія JR EAST ввела в експлуатацію нову інформаційноуправляючу систему COSMOS на високошвидкісних лініях Сінкансе. Попередня система COSMOS (система автоматизованого управління рухом) i SMIS (інформаційно-управляюча система) не справлялися 3 навантаженням при порушенні графіка руху поїздів [1]. COSMOS поставляє диспетчерам інформацію, потрібну для оцінки поїзної ситуації, і дозволяє вирішувати проблеми, що виникли. Вироблені в центрі управління дані передаються на станції і в інші пункти для установлення маршрутів i інформування пасажирів. Це зменшує навантаження на диспетчерів i iнший персонал, скорочуючи час, необхідний для відновлення руху поїздів після порушення графіка.

Система COSMOS дає можливість побачити графік-прогноз руху поїздів, який показує час прибуття i відправлення поїздів, базується на даних виконаного графіка. Графік-прогноз передається на станцію для управління поїздами на його основі. Такі прогнози дозволяють диспетчерам перевіряти наслідки результатів їх дій при відновленні нормального руху [1]. Це повинно поступово виправляти ситуацію i зменшувати завантаження на диспетчерський персонал при збоях в перевізному процесі.

У Франції національним об'єднанням французьких залізниць з 1990 р. експлуатується система ASTREE, в основі проекту якої закладені такі рішення: на кожному тяговому засобі встановлюється автономний пристрій, який визначає місце знаходження; база даних повинна мати достовірну поточну інформацію і оперативно іiі поновлювати; повинна бути створена система 3 декількох автоматизованих центрів управління i обробки даних на базі малих ЕВМ; повинен здійснюватися зв'язок АЦУ 3 поїздами i колійними пристроями по кабельних лініях. Система ASTREE будується за модульним принципом [1].

У Великобританії система автоматизованого управління i регулювання рухом поїздів (SATURN) забезпечує можливість відстеження проходження кожного поїзда через дільниці i відображання даних на відеопристроях [1].

Диспетчери можуть управляти пристроями СЦБ як в ручному, так і в автоматичному режимі. Ручне управління передбачається 3 АРМ диспетчерів центрі управління. Диспетчери спостерігають за переміщенням поїздів по дільниці шляхом погляду на табло. Додаткова інформація про поїзну роботу відображається диспетчерам на моніторах.

У Швеції в 1990 р. виконувалися роботи зі створення комп'ютерного ЦДУ для управління рухом поїздів у Стокгольмському регіоні 3 експлуатаційною довжиною 600 км. В ЦДУ є зал для поїзних і старших диспетчерів, приміщення енергодиспетчерів, центр навчання i тренажери. Границі диспетчерських кіл можна змінювати в залежності від інтенсивності руху поїздів [1].

В Італії в автоматизованій системі диспетчерського керування рухом поїздів на лінії 70 км 320 станцій Генуейського вузла автоматика центрального диспетчерського поста працює в жорсткому програмуванні або в режимі допомоги, при якому диспетчеру пропонується декілька можливих варіантів рішення для кожної конкретної ситуації і дається право вибору кожної з них [1].

Модуль інформації про рух поїздів i стан лінії показується в масштабі реального часу такими параметрами: місце знаходження, швидкість і запізнення поїзда, інформація про прохід поїзда через станції; закриті дільниці; стан переїздів. Існує також модуль прогнозу руху поїздів, 
що забезпечує прийняття рішення, статистичний аналіз.

Виконання системного контролю i управління рухом поїздів звільняє диспетчера від ручних операцій, як, наприклад, аналіз графіка руху поїздів i підготовка добових звітів.

При використанні графічних терміналів центральний диспетчер може контролювати загальний стан колії і рух поїздів. Можливі два види відображення поїзного положення: графічне i географічне. Обидва види відображення дозволяють аналізувати поточне положення 3 трьох різних рівнів деталізації: вся мережа, важливий вузловий пункт, ділянка лінії в межах одного відділку залізниці.

В Німеччині з 1990 р. створена єдина система контролю за рухом поїздів 3 використанням EBM is центрів диспетчерського контролю i управління (ЦДУ) [1]. Ця система не $є$ повністю автоматичною, на диспетчера покладається обов'язок прийняття рішення. Система надає всю необхідну інформацію про рух поїздів і статистичні дані.

Графік-прогноз автоматично корегується для поєднання його 3 нитками графіка виконаного руху. Це дозволяє диспетчеру швидше встановити конфлікти, що наближаються, та розв'язати їх, зміщуючи або задаючи нитки графіка за допомогою світлового пера. Великою перевагою використання ЕВМ $\epsilon$ можливість моделювання декількох варіантів і вибору кращих рішень, на основі яких визначається вказівка та передається черговим по станції.

На федеральних залізницях Австрії в ході розробки системи управління перевізним процесом особливу увагу приділяли АРM, що відповідали ергономічним вимогам.

Програмні модулі служать, перш за все, для порівняння планового графіка 3 графіком виконаного руху (ГВР), ведення архіву і статистики (приймання даних).
На федеральних залізницях Швейцарії ще в 1960 р. найбільші системи ДЦ були обладнані пристроями індикації номера поїзда. Це створило умови для автоматичного управління установки маршрутів. Для цього було введені управляючі ознаки перед номером поїздів [1].

Концепція телеуправління, розроблена ще 1970 р., передбачала три регіональні центри управління: в Лозанні, Люцерні, Цюріху. Вони з'єднувалися між собою і з центральним постом ДЦ (ЦП ДЦ). На другому рівні (оперативного управлінні) було намічено мати приблизно 30 ЦП ДЦ 3 трьома АРМ диспетчерів кожний. В період падіння обсягів перевезення роботу можна було сконцентрувати в одного диспетчера.

Всі відповідальні функції покладаються на нижній рівень централізації. Рівень оперативного управління i автоматизації не несе відповідальність за безпеку. Деякі компоненти системи управління повинні бути побудовані із захистом від небезпечних вказівок $з$ надійною обробкою відповідальних команд.

Диспетчер має можливість втручатися в роботу автоматики 3 можливістю реалізації автоматичного спостереження за рухом поїзда i зміни їх номерів, автоматичного установлення маршрутів.. Для залучення уваги диспетчерів використовується звукове i оптичне повідомлення.

Маршрут кожного поїзда може програмуватися індивідуально на кожну добу. Може бути автоматично сформований добовий графік. Реалізована можливість установлення маневрових маршрутів диспетчером за запитом, який надходить по радіозв'язку від маневрових бригад (до 15 бригад).

В Росії на залізницях введено в експлуатацію багато ДЦ і ДК. В 1990 р. була зроблена серйозна організація 3 аналізу і оцінки наявних розробок з метою проведення єдиної технічної політики при розвитку найбільш успішних розробок i 
створення типових рішень, в першу чергу у відношенні АРМ ДНЦ, ДГП, а також ДЦУ залізниць i центрів управління перевезень (ЦУП) [2].

В ДЦУ (рівня району, залізниці) використовується мікропроцесорна система ДЦ “Сетунь” (розробка ВНИИЖТ).

АРМ ДНЦ і ДГП функціонують на базі АСОУП і сигналів, отриманих від пристроїв залізничної автоматики (розробка фірми “Кант”).

АРМ поїзних диспетчерів функціонує на базі інформації, що знімається з системи залізничної автоматики і АСОУП (розробка фірми "Инфотекс").

Система АСДК - автоматизована система контролю технологічних процесів на залізничних вузлах, дільницях і станціях (розробка фірми "Ретайм").

Останніми роками робилися спроби організувати управління перевізним процесом на залізницях Росії на основі форсованого укріплення на залізничних коліях і створення трирівневої вертикалі управління: загальномережевий центр управління перевезеннями (ЦУП РЖД); сім регіональних центрів диспетчерського управління (РЦДУ); десять опорних центрів (ОЦ); управління лінійними центрами (ЛР) на кожній залізниці.

На даний час на ОАО "РЖД" створено регіональні центри диспетчерського управління відповідності 3 територіальним розділенням Росії на сім регіонів, як підрозділ мережевого ЦУП. До організації РЦДУ їх функції залишаються за дорожніми центрами диспетчерського управління. Створення ЦУП РЖД і інших центрів управління на стадії завершення [2].

В Україні розроблена система МСДЦ “Каскад”, яка введена в дію на дільниці руху прискореного поїзда Київ -
Дніпропетровськ. Вперше введена в експлуатацію на дільниці Вадим - Джанкой Придніпровської залізниці. На даний час працює на ділянках Київ - Зерново, Дарниця - Гребінка Південно-Західної залізниці, у Криворізькій дирекції залізничних перевезень Придніпровської залізниці і Дебальцівській дирекції залізничних перевезень Донецької залізниці. МСДЦ «Каскад» призначена для забезпечення заданої пропускної спроможності i безпеки руху при диспетчерському управлінні, входить до складу об'єктів автоматики на станціях, диспетчерської дільниці, та забезпечує автоматизування і максимальне спрощення операцій 3 управління рухом поїздів, зменшення навантаження на поїзних диспетчерів.

На мережі Укрзалізниці функціонує два ДЦУ на Південній залізниці (всі поїзні диспетчери переведені з дирекцій у ДЦУ) і на Донецькій залізниці. На інших залізницях ДНЦ знаходяться в дирекціях.

Висновки. Розвиток залізничного транспорту будь-якої країни тісно пов'язаний 3 якістю виконання експлуатаційної роботи, що у свою чергу безпосередньо залежить від оптимальності та ефективності управління на кожному piвні. Питання удосконалення диспетчерського управління $€$ одним 3 головних напрямків досягнення високого рівня організації роботи залізничного транспорту. I найбільш перспективним напрямком вирішення цього питання може бути саме формування перспективної автоматизованої системи диспетчерського управління на основі сучасних інформаційних систем та досвіду розробки і експлуатації подібних апаратів управління на залізницях розвинутих країн світу.

\section{Список літератури}

1. Гапанович, В.А. Системы автоматизации и информационные технологии управления перевозками на железных дорогах [Текст]: учеб. для вузов ж.-д. / В.А. Гапанович, 
А.А. Грачев [и др.]; под ред. В.И. Ковалева, А.Т. Осьмина, Г.М. Грошева. - М.: Маршрут, 2006. -544 c.

2. Программа первоочередных мер по повышению безопасности движения поездов на сети железных дорог ОАО “РЖД” [Электронный ресурс]: утв. 04.12.2003 г. - Режим доступа: http://doc.rzd.ru/doc/public?STRUCTURE_ID=704\&layer_id=5105\&refererLayerId=5104\&id=58 $15 \&$ print $=1$.

Ключові слова: диспетчерський персонал, автоматизація управління, автоматизоване робоче місце.

\section{Анотації}

У час інформаційних технологій країни 3 розвинутою мережею залізниць впроваджують інформаційні системи для допомоги диспетчерському персоналу в організації перевізного процесу. В роботі розглянуто досвід США, Росії та країн Свропи у впровадженні автоматизації систем диспетчерського управління рухом поїздів.

В век информационных технологий страны с развитой сетью железных дорог внедряют информационные системы для помощи диспетчерскому персоналу в организации перевозочного процесса. В работе рассмотрен опыт США, России и стран Европы во внедрении автоматизации систем диспетчерского управления движением поездов.

In the age of information technology of the country with a developed network of railways introduce information systems to help control tower personnel in the organization of the transportation process. This paper describes the experience of the U.S., Russia and European countries in the implementation of automation systems, supervisory control the movement of trains. 